\title{
SOME NOTONECTA FROM SOUTH AMERICA
}

\author{
BY H. B. Hungerford,
}

University of Kansas, Lawrence, Kansas.

The lack of precise external structural characters in the Genus Notonecta has led to almost hopeless confusion of the South American species. Fieber, unable to limit the range of variation within a species proposed many varietal names. Kirkaldy2 in his "Revision of the Genus Notonecta" disposed of a number of specific names by sinking them into synonomy This procedure has given a false impression of the relation of North and South American Notonecta. Kirkaldy, for illustration, considered the range of the most common North American Notonecta undulata Say to include Chile, South America. This was possible because he thought $N$. virescens Blanch. was only a variety of $N$. undulata Say. An examination of the genital capsules of the males will show plainly that they are distinct species. Other features less demonstrable but constant separate these species. N. virescens Blanchard is a good species.

Prior to Fieber's. Rhynchotographieen Guérin ${ }^{3} 1844$ described $N$. bifasciata from "les bords de la Platta." Then the same year that Fieber's paper appeared (1852) Blanchard's $N$. virescens was described. It appears that this species from Chile was unknown to Fieber. Fieber in his 1852 paper first describes $N$. nigra, a large and readily recognized species, the types of which are still in Vienna. Under Notonecta rugosa $(=N$. insulata Kirby) after naming three varieties from Long Island, Baltimore and Pennsylvania, he adds the variety basalis from Brazil. Under $N$. Variabilis he describes 4 varieties, the first one from Brazil and Porto Rico, the second from Baltimore, and the third and fourth from Brazil. I have not seen specimens of the

${ }^{1}$ Fieber, Franz Xavier: Rhynchotographieen-Prag (From Acten der Königl. Gesellschaft der Wissenschaften, Vol. V, Pt. 7.)

2Kirdaldy, G. W.: Revision of the Notonectidae Part I. Introduction and Systematic Revision of the Genus Notonecta. Trans. Ento. Society of london. 1897.

3Cruérin-Ménéville, Félix Edouard: Iconographie dı Règne Animal de G. Cuvier ..Paris-1829-1844. 
common United States species which we call $N$. variabilis from Brazil and am inclined to believe that it does not exist there. If the first named variety of Fieber's $N$. variabilis is to be taken as the type, I should be inclined to the opinion that the name maculata which Fieber gave to his variety from Baltimore should be used as Fieber's name for our North American species. His description fits our insect very well. The size is too small to be applied to our common $N$. undulata Say which Fieber appears to have known only from the literature describing this insect under other names. It happens, however, that the name $N$ maculata was employed previously by Fabricius. I suggest the name Notonecta lunata for the North American species which we have hitherto called $N$. variabilis. A figure of the male genital capsule is shown on Plate XXXI, Fig. 11 of Kansas University Science Bulletin No. XI.

Under $\dot{N}$. polystolisma Fieber describes 5 varieties, four of them from Brazil and probably various color phases in the development of the color pattern of one species. One variety which he called sellata came from Buenos Aires and is most certainly $N$. bifasciata Guérin. Kirkaldy and Bueno call $N$. polystolisma Fieber a synonym of $N$. bifasciata Guérin.

There have come to my hand for determination several small species of Notonecta from South America. No one seems to have given these insects the close scrutiny necessary to separate the species. As will be seen by the drawings submitted, there are distinct structural characters. There are also characteristic color patterns, but much confusion can arise because of the teneral specimens taken in various stages of pigmentation. It also happens that in some of these species there are two color phases - the pale immaculate forms as well as the nearly black forms, a condition similar to that of the well known Notonecta shooteri Uhler.

Notonecta bicirca sp. nov.

Size: Length, $9 \mathrm{~mm}$; width, $3 \mathrm{~mm}$. Some are a little larger and some a little smaller than the measurements given. 
Color: General view shows head, prothorax and legs yellowish. Scutellum and two circles on hemelytra black. Closer inspection reveals posterior half of pronotum darkened by black thorax beneath, an elongate yellow spot on lateral margins of scutellum. Hemelytra yellowish-white covered with silvery hairs and with the following typical maculations: Submarginal band of black on base of corium; distal end of clavus black; base of corium; distal end of clavus black; broad transverse black band traversing distal third of corium and base of membrane and embracing a small orange-yellow spot at end of embolium and entirely surrounding a much larger nearly circular spot above. The general effect produced is that of two black circles surrounding orange-yellow spots upon the insects, the lateral orange yellow spots upon the margins of the wings and opening upon the embolial sutures being unnoticed.

Structural characteristics: The eyes farther apart at synthlipsis than in others of this group of species. Vertex: synthlipsis : : $10: 4$. Anterior width of pronotum : posterior width of pronotum : $: 23: 33$. The genital capsule of the male is shown on Plate II, Figure 1.

Described from 50 specimens from Chile. Taken by Doctor Alfredo Faz. 15 of them from Santiago and the others from Termas Cauquenes. Holotype, allotype and some paratypes in author's collection. Others in United States National Museum.

\section{Notonecta disturbata sp. nov.}

Size: Length, $8 \mathrm{~mm}$; width, $2.9 \mathrm{~mm}$.

Color: Of two color phases. One yellowish-white throughout. The other with yellowish-white head, anterior half of pronotum and legs; basal half of hemelytra and tip of membrane white; scutellum and remainder of hemelytra black.

Structure: The eyes fairly close at synthlipsis. Vertex: synthlipsis : : $10: 2.3$. The width of the eye at base less than width of vertex. Sides of pronotum convergent. Anterior width of pronotum: posterior width of pronotum : : $19: 29$. The genital capsule of the male is shown Plate II, Figure 2. 

Brazil.

Described from specimen belonging to São Paulo Museum,

Notonecta minuta sp. nov.

Size: Length, $7.2 \mathrm{~mm}$; width, $2 \mathrm{~mm}$.

Color: General view shows head, pronotum, legs and basal third of hemelytra yellow. Scutellum and distal two-thirds of hemelytra black with tips of membrane yellowish. Upon closer study there are seen to be enclosed in the broad black area across the hemelytra four small irregular orange yellow spots of nearly equal size. On one of the three specimens there are ill defined yellowish spots near the base and at the tip of the scutellum.

Structural characteristics: Vertex : synthlipsis : : $9: 2.1$. The width of eye at base equal to the width of vertex. Interior width of pronotum : posterior width of pronotum $:: 19: 26$. The genital capsule of the male is shown on Plate II, Figure 7.

Described from specimens in the Carnegie Museum bearing the label, "Prov. del Sara, Bolivia, 450 m. J. Steinbach."

Notonecta pulchra sp. nov.

Size: Length, $8 \mathrm{~mm}$; width, 3-mm.

Color: Head, anterior half of pronotum, and legs yellow. Scutellum and hemelytra black save two pale spots at base of wings and an orange, irregular, transverse band at end of corium. Silvery hairs on hemelytra. A beautiful and striking species.

Structural characteristics: Vertex : synthlipsis : : $11: 3$. The vertex being broader than the width of eye at its base. The anterior width of pronotum : posterior width of pronotum $:: 22$ $: 32$. The genital capsule of male is shown on Plate II, Figure 3 . Villa Rica by Mr. F. Schade. Holotype, allotype and many paratypes in author's collection. Paratypes also placed in United States National Museum. 
Notonecta polystolisma Fieb. var. spatulata var. nov.

Fieber described five varieties under this species, one of which is quite certainly $N$. bifasciata. The other four are from Brazil and appear to be stages of pigmentation of a single species. Three of them he describes as having the "Schild gelblich." The species which I have may be related to them, but since it does not fit any of his descriptions it seems best to give it at least a varietal name. In the twenty specimens I have before me the scutellum is typically black and none of them surpass 4 lines in length. The vertex : synthlipsis : $: 10: 3$. The anterior width of pronotum : posterior width of pronotum : : $23: 35$. The genital capsule of male is shown on Plate II, Figure 9. Described from 20 specimens from São Paulo, Brazil. Holotype, allotype and some paratypes taken at Ypirango, S. A. by R. Spitz. Others from São Paulo, Brazil, by unknown collector. Holotype, allotype, and some paratypes in author's collection. Others in the Museum of São Paulo.

\section{Notonecta bifasciata Guér.}

I have this species from Paraguay and various places in Argentina. The genital claspers in the male are quite different from any of the other species of this size (see Plate II, Figure 5.) It appears to be a common and abundant species.

\section{Description of Plate II.}

Notonecta bicirca sp. nov. Chile. Figure 1.

Notonecta disturbata sp. nov. Brazil. Figure 2.

Notonecta pulchra sp. nov. Paraguay. Figure 3.

Notonecta bifasciata Guér. Argentina. Figure 5.

Notonecta minuta sp. nov. Bolivia. Figure 7.

Notonecta polystolisma Fieb. var. spatulata var. nov. Figure 9, Figures 4,6 and 8 are of previously named species but not of this series. 

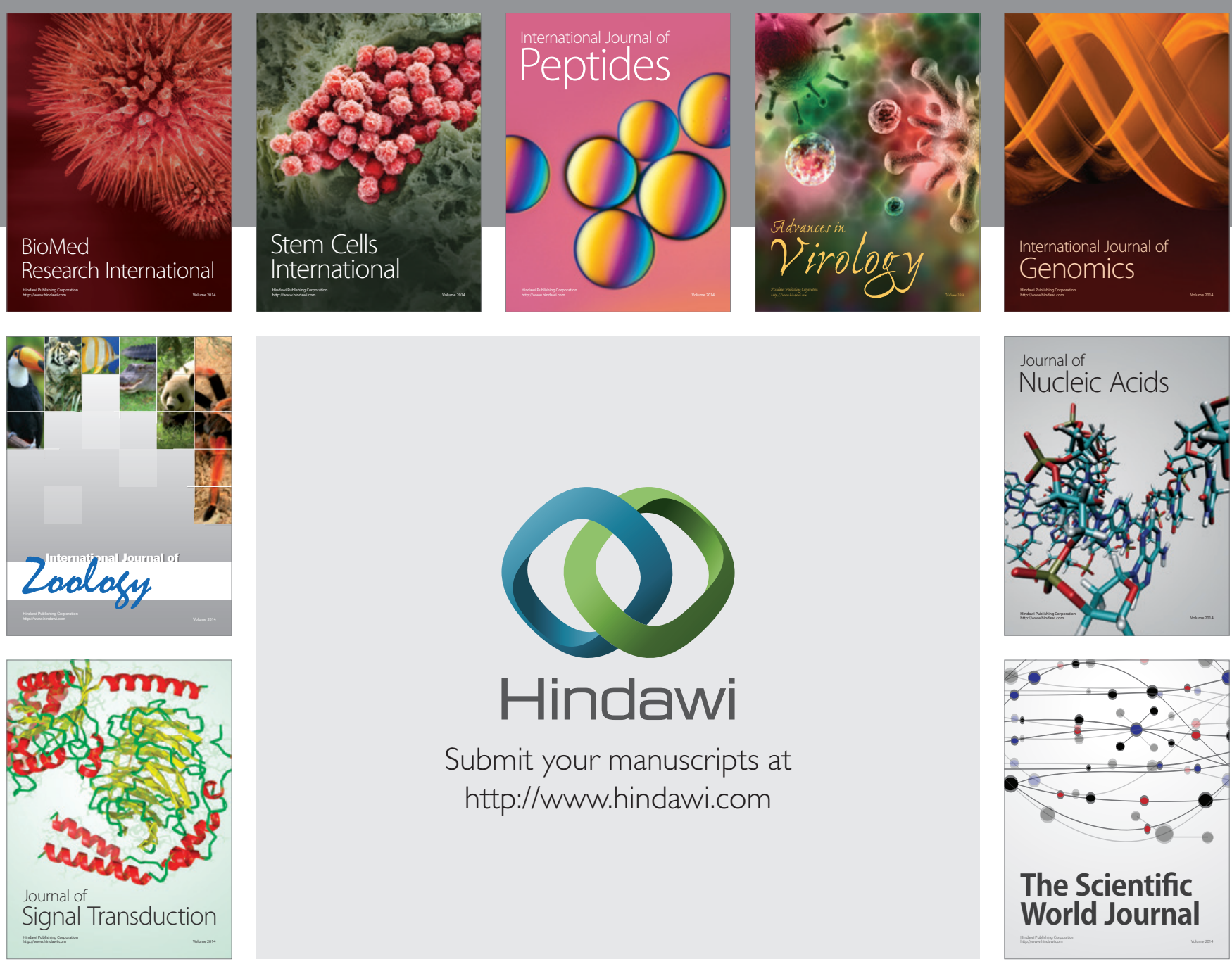

Submit your manuscripts at

http://www.hindawi.com
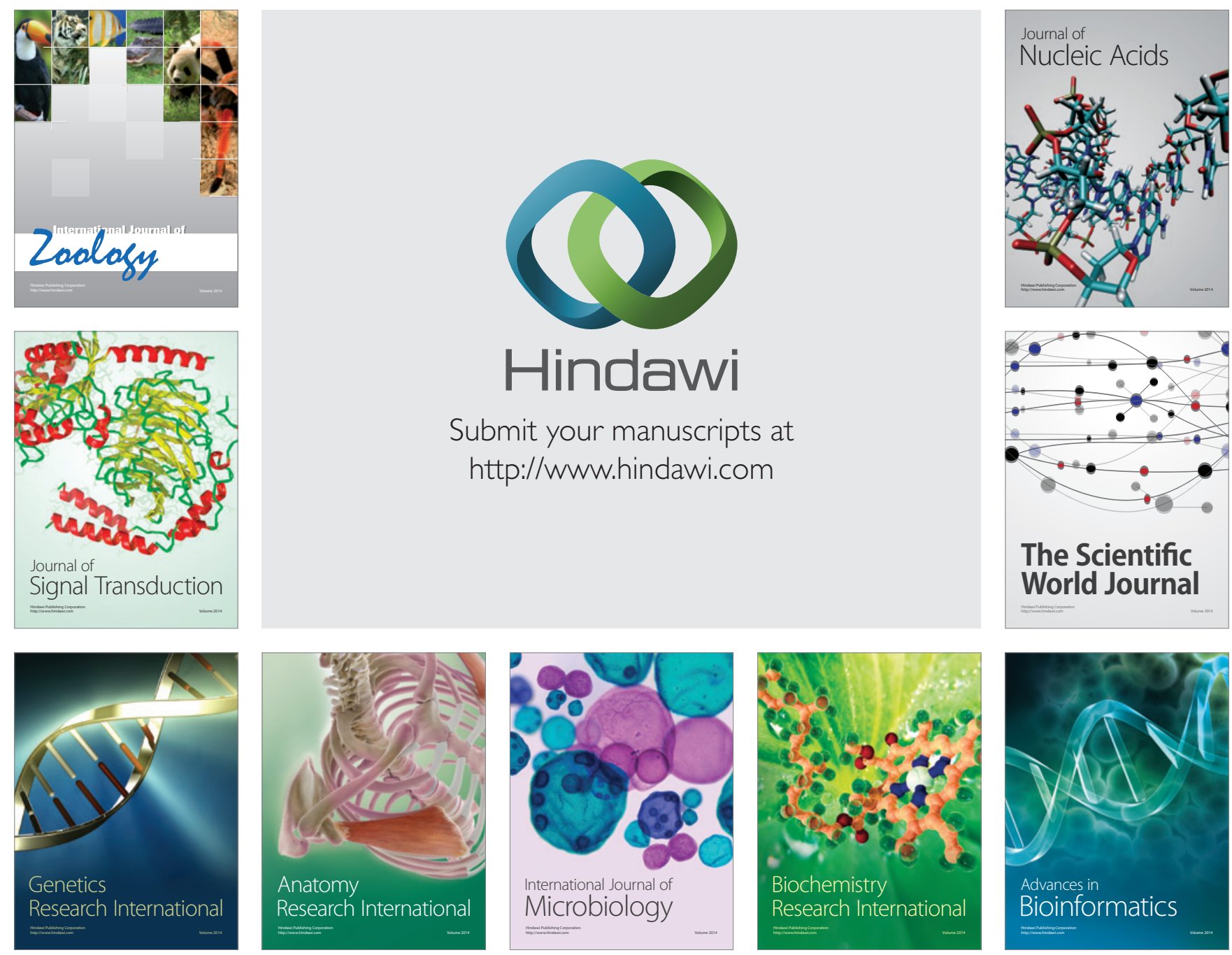

The Scientific World Journal
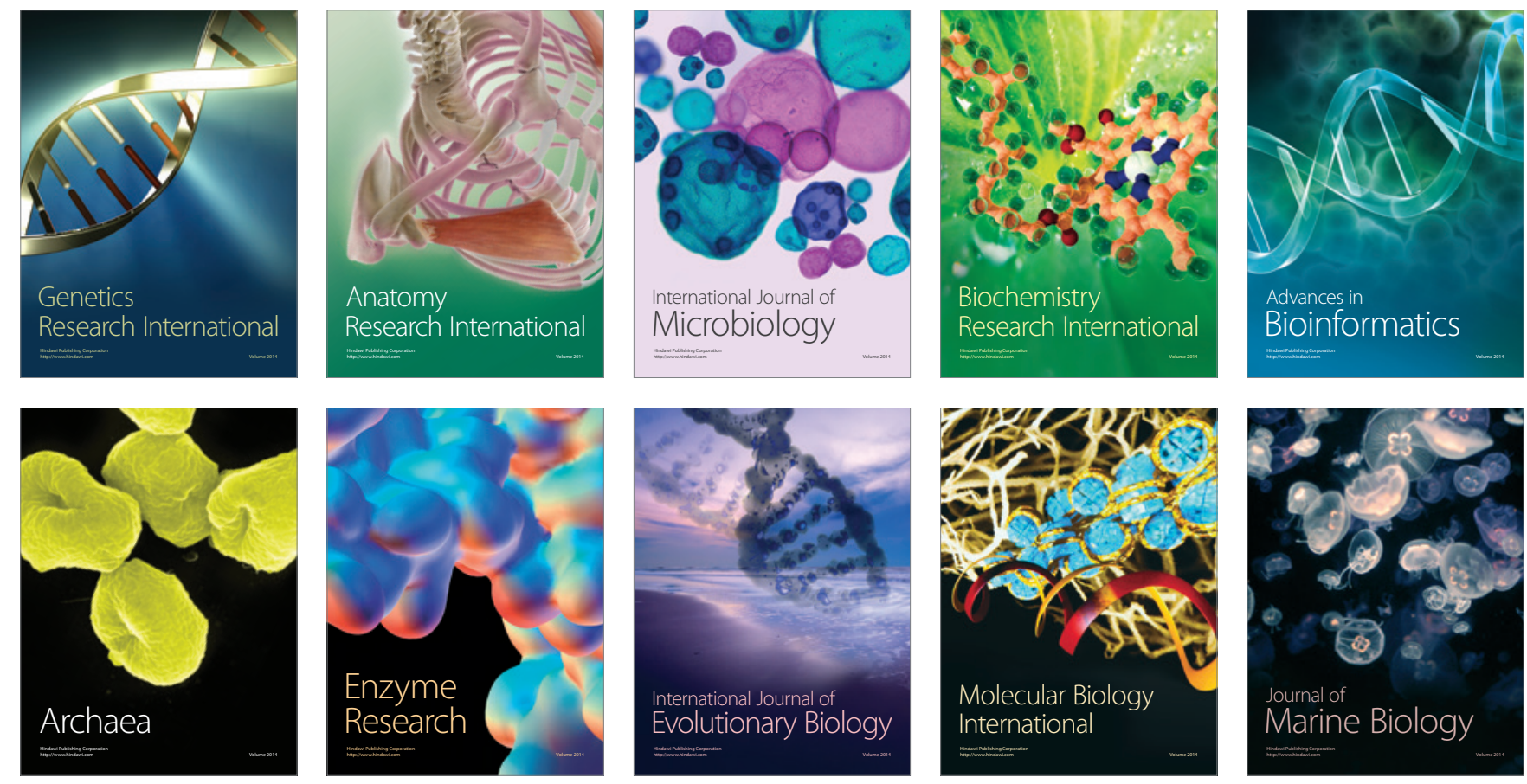